\title{
Impact of environmentally friendly technologies on costs and cost-effectiveness of a dairy cattle confinement system
}

\author{
Impacto da adoção de tecnologias ambientalmente \\ corretas no custo de produção do leite e na \\ rentabilidade de um sistema de produção em \\ confinamento total
}

\begin{abstract}
Marcos Aurélio Lopes ${ }^{1 *}$; Fabiana Alves Demeu2; Eduardo Mitke Brandão Reis ${ }^{3 ;}$ Francisval de Melo Carvalho4; André Luiz Ribeiro Lima*; Gideon Carvalho de Benedicto4; Gastão Lemos Barbosa5; Andreia Alves Demeu6; Marcos Aurelio Lopes Filho7; Matteo Barbari ${ }^{8}$
\end{abstract}

\section{Highlights}

The economic impact of some environmentally friendly technologies was assessed.

The TEOC was on average $\mathrm{R} \$ 0.015 / \mathrm{kg}$ milk and represented $1.985 \%$ of the TOC.

The EOC was on average $\mathrm{R} \$ 0.0059 / \mathrm{kg}$ milk and corresponded to $0.7788 \%$ of the TOC.

The TEC was R $\$ 0.0317$ / kg milk and stood for 3,3280\% of the total cost (TC).

Some of the studied technologies proved to be economically feasible.

\begin{abstract}
Our goal was to assess the economic impact of some environmentally friendly technologies on the production costs and cost-effectiveness of a dairy cattle confinement system, estimating environmental costs and their representativeness in both effective and total operating costs, as well as in the total cost.

1 Ful Prof., Department of Veterinary Medicine, Federal University of Lavras, UFLA, Lavras, MG, Brazil. E-mail: malopes@ufla.br

2 PhD Student in the Veterinary Sciences Graduate Program, Federal Institute of Rondônia, IFRO, RO, Brazil. E-mail: fabiana.alves@ifro.edu.br

3 Prof., Federal University of Acre, UFAC, Rio Branco, AC, Brazil. E-mail: edumitke@gmail.com

4 Profs., Department of Business and Economy, UFLA, Lavras, MG, Brazil, UFLA, Lavras, MG, Brazil. E-mail: francarv@ ufla.br; andre.lima@ufla.br; gideon.benedicto@ufla.br

5 Self-Employed Veterinary Physician, Boa Esperança, MG, Brazil. E-mail: gastat@boaesperanca.com.br

6 Self-Employed Zootechnician, Porto Velho, RO, Brasil. E-mail: demeuaa@gmail.com

7 PhD Student in the Global Health and Sustainability Graduate Program, University of São Paulo, USP, São Paulo, SP, Brazil. E-mail: marcos.lopes.fh@gmail.com

8 Prof., University of Florence, Università Degli Studi Di Firenze, UNIFI, Italy. E-mail: matteo.barbari@unifi.it

* Author for correspondence
\end{abstract}

Received: July 30, 2020 - Approved: Mar. 05, 2021 
We assessed the cost-effectiveness of the cost center of milk production and identified the components that most affect final costs, estimating a break-even point (kg milk year-1) as well. The data were collected in a freestall full-confinement system of a dairy cattle farm located in southern Minas Gerais State (Brazil), from January 2016 to December 2017. The cost of milk production was estimated using a method based on the operating and total costs from a cost center involving lactating and dry dairy cows. The cost center of milk production showed to be economically feasible, showing positive gross and net margin results, as well as positive profitability and cost-effectiveness. Total environmental operating cost was on average $\mathrm{R} \$ 0.015$ per $\mathrm{kg}$ milk, which represented $1.985 \%$ of the total operating cost. Effective environmental operating cost was on average $\mathrm{R} \$ 0.0059$, which corresponded to $0.7788 \%$ of the total operating cost. Finally, total environmental cost was on average $\mathrm{R} \$ 0.0317$, representing $3.3280 \%$ of the total cost. The most representative items of the effective operating cost were in descending order: animal feed, workforce, animal health, animal production hormone (bovine somatotropin; bST), vehicle maintenance, machines and equipment, maintenance of improvements, electricity, and freestall bedding sand. Average break-even point was $1,104,038.54 \mathrm{~kg}$ milk year-1 ${ }^{-1} 3,024.76 \mathrm{~kg}$ milk day ${ }^{-1}$, while average production was 4,271,383.00 kg milk year $^{-1}$ and $11,702.42 \mathrm{~kg}$ milk day $^{-1}$.

Key words: Environment. Dairy Cattle. Environmental cost. Cost-effectiveness. Sustainability.

\section{Resumo}

Objetivou-se analisar o impacto econômico da adoção de algumas tecnologias ambientalmente corretas no custo de produção do leite e na rentabilidade de um sistema de produção, bem como estimar o custo ambiental e a sua representatividade no custo operacional efetivo, no custo operacional total e no custo total. Especificamente, pretendeu-se, ainda, analisar a rentabilidade do centro de custo produção de leite, identificar os componentes que exercem maiores representatividades sobre os custos finais da atividade e estimar o ponto de equilíbrio ( $\mathrm{kg}$ de leite $\mathrm{ano}^{-1}$ ). Os dados foram coletados no período de janeiro de 2016 a dezembro de 2017 em um sistema de produção de leite localizado ao Sul de Minas Gerais, em confinamento total, do tipo freestall. O custo de produção do leite foi estimado segundo a metodologia do custo operacional e custo total, considerando o centro de custo produção de leite, que envolveu as vacas em lactação e as secas. O centro de custo leite apresentou viabilidade econômica, com margens bruta e líquida, bem como resultado positivo, assim como lucratividade e rentabilidade positivas. O custo ambiental operacional total médio de um quilograma de leite foi estimado em $\mathrm{R} \$ 0,015$ e representou 1,985\% do custo operacional total; o custo operacional efetivo ambiental médio foi de $R \$ 0,0059$, e correspondeu a $0,7788 \%$ do custo operacional total; enquanto que o custo ambiental total médio, estimado em $\mathrm{R} \$ 0,0317$, representou $3,3280 \%$ do custo total. Os itens componentes do custo operacional efetivo que exerceram maiores representatividades foram, em ordem decrescente, a alimentação, mão-de-obra, sanidade, hormônio produtivo (BST), manutenção de veículos, máquinas e implementos, manutenção de benfeitorias, energia e areia para cama do free stall. O ponto de equilíbrio médio foi estimado em $1.104 .038,54 \mathrm{~kg}$ de leite $a^{-1}$, ou $3.024,76 \mathrm{~kg}$ de leite dia-1 ${ }^{-1}$ enquanto que a produção média foi de $4.271 .383,00 \mathrm{~kg}$ de leite ano-1 e $11.702,42 \mathrm{~kg}$ de leite $\mathrm{dia}^{-1}$.

Palavras-chave: Meio ambiente. Bovinocultura leiteira. Custo ambiental. Rentabilidade. Sustentabilidade. 


\section{Introduction}

Besides its financial GDP contribution, the dairy cattle agribusiness plays a highly relevant social role in Brazil, as several farmers have milk as their main source of income (Bergamaschi, Machado, \& Barbosa, 2010). This contributes to the settlement of thousands of families in rural areas and generation of millions of direct and indirect jobs.

In the last three decades, the international community has promoted models of social, economic, and environmentally sustainable development (United Nations General Assembly [UN], 1992). However, the prevalence of people under food and nutrition insecurity, together with the emerging climate crisis, has placed sustainable agriculture at the center of the 2030 Agenda for Sustainable Development (2015), which was unanimously adopted by the United Nations member states. The targets 2 and 17 of the international agreement reinforce that the development, spread, and use of environmentally friendly technologies in agricultural production systems are essential to ensure continuity of human life on Earth (United Nations General Assembly [UN], 2015). Therefore, despite few in number, some studies have been carried out on the environmental sustainability of dairy farming systems (Herzog, Winckler, \& Zollitsch, 2018; Reddy et al., 2019).

Dairy farming has not always shown positive results (Lopes, Santos, \& Carvalho, 2011d; Santos \& Lopes, 2014), and any rise in production costs can make it unfeasible and hence worsen farmer situations even further. Some studies have assessed milk production cost for some years by economic analysis of milk exploration (Assis et al., 2017; Moura et al., 2010), using economic and cost-effectiveness indicators of the cost center of milk production systems (Lopes \& Santos, 2013; Santos \& Lopes, 2012, 2014) and production cost of bovine females (Lopes et al., 2010; Reis, Lopes, Santos, \& Guimarães, 2018).

Despite the importance of the theme, studies have not considered environmental costs and their effects on effective operating cost due to the use of biogas-generated electricity, sand reclamation for freestall bedding, rainwatercollectionforfurtheruse, and waste and effluent use as fertilizers. Although adding environmental cost information would enrich and allow users to assess the magnitude of environmental investments compared to equity and results over the period (Kraemer, 2001), there are no studies in the literature estimating environmental costs for dairy farming.

In this sense, our study aimed to analyze the impact of some environmentally friendly technologies on the production cost and costeffectiveness of a milk production system under full confinement, as well as estimate environmental cost and its representativeness within the effective operating cost, total operating cost, and total cost. Specifically, we assessed the cost-effectiveness of dairy farming in southern Minas Gerais State by identifying the most representative components in final costs, estimating a breakeven point.

\section{Material and Methods}

The survey was performed on a farm located in the city of llicínea, in the south of the State of Minas Gerais (Brazil), between January 2016 and December 2017. It covers an area of 504 hectares and develops coffee 
farming, pig breeding, and dairy farming. Our study was focused on a 100-ha area, in which environmentally friendly infrastructures for rainwater collection, sand reclamation for freestall bedding, and a Canadian-type biodigester for electricity generation were implemented.

The farm holds an intensive dairy farming activity, with housing for all lactating and pre-calving cows in two freestall sheds with dimensions of $90 \times 30 \mathrm{~m}$ (shed 1) and $60 \mathrm{~m} \times 30 \mathrm{~m}$ (shed 2), wherein 230 and 198 single beds were installed, respectively. These stalls had housing capacities of about 428 Holstein cows, pure by crossing or by pure source. Average daily yield reaches $11,864.95$ $( \pm 1,388.79)$ and about 32.28 ( \pm 2.68$) \mathrm{L}$ milk per lactating cow, from three milking sessions a day. A complete diet, with corn silage (Zea mays) and concentrate, was provided on a feeding lane thrice daily.

The farm was selected according to the following criteria: livestock and economic data availability and quality, rancher consent and interest in the research, and ease of data access to researchers (Lopes et al., 2015). Farm files were consulted for data collection concerning actual operating expenses and revenues. To this end, we used field handbooks prepared for the purpose. Both expenses and revenues related to the cost center of the milk production system, which involves lactating and dry dairy cows, were considered. Then, these were allocated to specific groups of the cost center in question.

Items composing effective operating cost (EOC) were divided into the following groups: animal feed, workforce, electricity, artificial insemination, bovine somatotropin
(bST), animal health care, milking, taxes, and miscellaneous expenses. Yet revenues comprised sales of milk, animals, by-products (manure from biodigester), and obsolete objects, according to the method of Lopes et al. (2019) and Pelegrini et al. (2019).

A rate of $6.99 \%$ was adopted for return on working capital, considering $20 \%$ of the EOC, as recommended by Lopes et al. (2016). Yet for return on land investment, we adopted a value of two liters of milk per day and per hectare ( $\mathrm{R} \$ 70.00$ per ha month-1).

The data were registered in a spreadsheet developed specifically for electronic data processing. It included both production cost structures: total production cost, which comprises fixed and variable costs, both used by Lopes et al. (2019) and Pelegrini et al. (2019). In this study, we used the linear depreciation method developed by Moraes et al. (2018). For depreciation of breeding cows, we adopted the method used by Santos and Lopes (2012), and for heifer acquisition, an initial value of $\mathrm{R} \$ 8,000.00$ (US\$2,453.99), which corresponds to the average price for the on-farm sale of heifers during the study period. Lifespan (5 years) was estimated according to the rate of involuntary disposal. As a final value, fat cows (550 kg live weight) were sold for R\$ 105.54 (US\$ 32.27). Biodigester was used in both cattle and pig farming; therefore, the allotment of animals was proportional to expectations in terms of electricity generation from waste produced, considering the number of animals and waste production estimates, as proposed by Santos (2012). For dairy farming, estimates were 11.73 and $12.12 \%$ for 2016 and 2017 , respectively. 


\section{Results and Discussion}

Table 1 presents a summary of the resources available in the cost center of the dairy cattle farm studied. These resources were used in the analysis and discussion of our findings. Equity investment, without land value, to mitigate environmental impacts was $\mathrm{R} \$ 577,197.88$, which represented $6.33 \%$ of all investments in the production system, among which the groups of improvements $(2.85 \%)$ and machinery $(2.83 \%)$ were the most representative, while equipment and implements represented only $0.65 \%$. Regarding the technologies, biodigester was responsible for $3.80 \%$ of the total investments, followed by the sand reclamation system $(1.31 \%)$ and rainwater collection (1.21\%). The area destined for these technologies represented $1.28 \%$ of the total area of the farm. Due to the originality of our study, no studies were found in the literature for comparisons; however, our findings cannot be considered too expressive and may serve as a reference for further surveys. They can also be used to assist technicians and ranchers in decisionmaking for the adoption of such technologies. Table 1 describes in detail the investments made in technologies.

Table 1

Resources available in the cost center of milk production in a dairy cattle farm with a freestall system in southern Minas Gerais State from January 2016 to December 2017, in R\$ and \%.

\begin{tabular}{|c|c|c|c|}
\hline Specification & Value (R\$) & $\begin{array}{l}\text { (\% to the } \\
\text { total) }\end{array}$ & $\begin{array}{c}\text { (\% to } \\
\text { environmentally } \\
\text { friendly } \\
\text { technologies) }\end{array}$ \\
\hline Total value of land equity ( $\mathrm{R} \$)$ & $4,936,800.00$ & 35.11 & - \\
\hline $\begin{array}{l}\text { Equity value of land occupied with environmentally } \\
\text { friendly technologies }(R \$)\end{array}$ & $63,000.00$ & 1.28 & 9.84 \\
\hline $\begin{array}{l}\text { Equity value without considering land } \\
(R \$)(A+B+C+D+E+F+G)\end{array}$ & $9,123,700.50$ & 64.89 & - \\
\hline $\begin{array}{l}\text { Equity value in environmentally friendly technologies } \\
\text { without land }(\mathrm{R} \$)(I+I I+I I I+I V+V+V I+V I I+V I I I+I X)\end{array}$ & $577,197.88$ & 6.33 & 90.16 \\
\hline $\begin{array}{l}\text { Equity value without considering land and animals } \\
(A+B+C+E+F+G)\end{array}$ & $6,353,700.50$ & 45.19 & - \\
\hline A - Total amount spent on improvements $(\mathrm{R} \$)$ & $4,416,887.33$ & 48.41 & 100.00 \\
\hline $\begin{array}{l}\text { Total amount spent on improvements with } \\
\text { environmentally friendly technologies (I + II + III) }\end{array}$ & $260,037.88$ & 100.00 & 2.85 \\
\hline I - Biodigester & $132,374.00$ & 50.91 & 1.45 \\
\hline II - Sand reclamation & $47,707.68$ & 18.35 & 0.52 \\
\hline III - Rainfall collection & $79,956.20$ & 30.75 & 0.88 \\
\hline$B$ - Amount spent on equipment and implements ( $R \$)$ & $749,744.50$ & 8.22 & - \\
\hline
\end{tabular}


contuation...

\begin{tabular}{|c|c|c|c|}
\hline $\begin{array}{l}\text { Total value in equipment, implements and tools with } \\
\text { environmentally friendly technologies (IV + V + VI) }\end{array}$ & $59,400.00$ & 100.00 & 0.65 \\
\hline IV - Biodigester & $5,000.00$ & 8.42 & 0.05 \\
\hline V - Sand reclamation & $54,400.00$ & 91.58 & 0.60 \\
\hline VI-Rainfall collection & 0.00 & 0.00 & 0.00 \\
\hline C - Amount spent on machines ( $R \$)$ & $501,000.00$ & 5.49 & - \\
\hline $\begin{array}{l}\text { Total amount on machines with environmentally friendly } \\
\text { technologies (VII + VIII + IX) }\end{array}$ & $257,760.00$ & 100.00 & 2.83 \\
\hline VII - Biodigester & $210,000.00$ & 81.47 & 2.30 \\
\hline VIII - Sand reclamation & $17,760.00$ & 6.89 & 0.19 \\
\hline IX - Rainfall collection & $30,000.00$ & 11.64 & 0.33 \\
\hline $\mathrm{D}$ - Amount spent on animals ( $\mathrm{R} \$)$ & $2,770,000.00$ & 30.36 & - \\
\hline E -Amount on livestock $(R \$)$ & 0.00 & 0.00 & - \\
\hline F -Amount on furniture ( $R \$)$ & $1,050.00$ & 0.01 & - \\
\hline G - Amount on vehicles $(\mathrm{R} \$)$ & 0.00 & 0.00 & - \\
\hline \multirow[t]{2}{*}{ Total fixed assets $(R \$)(A+B+C+D+E+F+G)$} & $13,112,827.71$ & 100.00 & - \\
\hline & $577,197.88$ & 4.40 & 100.00 \\
\hline Area for bovine farming (ha) & 98.74 & 98.74 & 0.02 \\
\hline $\begin{array}{l}\text { Area occupied with environmentally friendly technologies } \\
\text { (ha) }\end{array}$ & 1.26 & 1.26 & 1.26 \\
\hline Total area (ha) & 100.00 & 100.00 & 100.00 \\
\hline Total fixed assets per ha $\left(\mathrm{R} \$ \mathrm{ha}^{-1}\right)$ & $131,128.28$ & 1.00 & - \\
\hline $\begin{array}{l}\text { Total fixed assets on environmentally friendly } \\
\text { technologies per ha }\left(\mathrm{R} \$ \mathrm{ha}^{-1}\right)\end{array}$ & $5,771.98$ & 0.04 & 100.00 \\
\hline $\begin{array}{l}\text { Fixed assets per lactating breeding cow }(\mathrm{R} \$ \text { breeding } \\
\left.\mathrm{cow}^{-1}\right)^{*}\end{array}$ & $37,137.64$ & 2.83 & - \\
\hline $\begin{array}{l}\text { Fixed assets on environmentally friendly technologies per } \\
\text { lactating breeding cow }\left(\mathrm{R} \$ \text { breeding } \operatorname{cow}^{-1}\right)^{*}\end{array}$ & 817.04 & 0.14 & 0.14 \\
\hline Fixed assets per liter milk sold $\left(\mathrm{R} \$ \mathrm{~kg}^{-1}\right)$ * & 1.59 & 0.00 & - \\
\hline $\begin{array}{l}\text { Fixed assets on environmentally friendly technologies per } \\
\text { liter milk sold }\left(\mathrm{R} \$ \mathrm{~kg}^{-1}\right)^{*}\end{array}$ & 0.07 & 0.00 & 0.00 \\
\hline Fixed assets per housed cow capacity $\left(\mathrm{R} \$\right.$ bed $\left.^{-1}\right)$ & $19,102.87$ & 0.15 & 0.15 \\
\hline $\begin{array}{l}\text { Fixed assets on environmentally friendly technologies per } \\
\text { housed cow capacity }\left(\mathrm{R} \$ \text { bed }^{-1}\right)\end{array}$ & $1,348.59$ & 0.010 & 0.010 \\
\hline
\end{tabular}

US\$1.00 equals $R \$ 3.26$, the average exchange rate from January 01 to December 31 of 2017 (Banco Central do Brasil [BCB], 2018).

* AVERAGE OF THE YEARS 2016 AND 2017. 
As for other investments made by the rancher in the milk production process, "land ownership" stood out for being, on average, $35.11 \%$ of the total fixed assets (Table 1) in 2016 and 2017. This percentage was near the $38.21 \%$ obtained by Lopes et al. (2012), but below the $42.32 \%$ by Santos and Lopes (2014) and the $53.26 \%$ by Silva et al. (2019). These differences may be due to land value variation with location, soil type, and tillage intensification level. Thus, the best land use is one of the issues that should be addressed by technicians and ranchers, which may justify the intensification of production systems, mainly where land values are higher.

"Equity value without land" was the most representative (64.89\%) (Table 1). This is higher than the findings of Santos and Lopes (2014) (61.79\%; an average of three production systems), Santos and Lopes (2012) (57.68\%; an average of three production systems), and Silva et al. (2019) (46.74\%). This superiority might be due to investments in environmentally friendly technologies (R \$577,197.88), which represented $6.33 \%$ of the total. If this value is added to the one obtained by Santos and Lopes (2012) (57.68\%), this value would reach $64,01 \%(57.68+6.33)$, that is, quite similar to one found by this research.

The average of total fixed assets, without land and animal values, was $R \$$ 6,353,700.50 in 2016 and 2017 (Table 1). It corresponded to $45.19 \%$ of the investments made on the farm and very similar to that of the study of Silva et al. (2019) (46.74\%).

Animals represented, on average, $30.36 \%$ of the equity without land in 2016 and 2017 (Table 1), which is well below the average of the three systems assessed by Santos and Lopes (2012) (48.05\%). These authors also highlighted the importance of concerning animal expenses from purchase to daily handling, environment quality, among others, to maximize productivity and hence return on capital. Investments in breeding cows are considered fixed costs (FC); therefore, higher yields per animal must be "diluted" to reduce percentages of such expenses in the total cost (TC).

The total of fixed assets per ha was $\mathrm{R} \$ 131,128.28$ (Table 1), which is superior to the estimate by Santos and Lopes (2014) (R\$ 25,990.47), despite the accumulated inflation by the Brazilian Consumer Price Index - IPCA (Instituto Brasileiro de Geografia e Estatística [IBGE], 2018) (R\$ 73,743.51). According to these researchers, such an indicator can be used to assess land-use intensification.

Table 2 shows a summary of the cost-effectiveness analysis. Total revenue corresponded to the sum of values raised by sales of milk, animals, and by-products (biofertilizers). Milk yield had the greatest contribution to total revenue (95.48 and $95.14 \%$ in 2016 and 2017, respectively). These were above the $93.15 \%$ observed by Silva et al. (2019), but below the $98.16 \%$ by Santos and Lopes (2012, 2014). Moreover, sales of biofertilizers had an average contribution of $2.415 \%$. These values and their representativeness were similar in both years (Table 2). Although many dairy ranchers do not pay due attention to by-products (e.g., manure and biofertilizer) as a source of revenue, manure can represent up to $3.64 \%$ of the total revenue, as mentioned by Silva et al. (2019). In our study, manure was not considered as a byproduct due to its use in biodigester for biogas production and electricity generation. 
Table 2

Summary of profitability analysis in the cost center of milk production on a dairy cattle farm with freestall system in southern Minas Gerais State (Brazil), between January 2016 and December 2017, in $\mathrm{R} \$$ and \%

\begin{tabular}{|c|c|c|c|c|}
\hline \multirow{2}{*}{ Specification } & \multicolumn{2}{|c|}{ Year: 2016} & \multicolumn{2}{|c|}{ Year: 2017} \\
\hline & Total value & $\%$ & Total value & $\%$ \\
\hline Revenue (R\$) & $6,720,611.10$ & 100.00 & $6,691,390.02$ & 100.00 \\
\hline Milk (R\$) & $6,416,695.45$ & 95.48 & $6,366,474.37$ & 95.14 \\
\hline Animals (R\$) & $142,000.00$ & 2.11 & $163,000.00$ & 2.44 \\
\hline By-products - biofertilizer (R\$) & $161,915.65$ & 2.41 & $161,915.65$ & 2.42 \\
\hline Total operating cost (TOC) (R\$) & $3,960,781.88$ & 100.00 & $4,110,055.34$ & 100.00 \\
\hline Effective operating cost (EOC) (R\$) & $3,166,409.50$ & 79.94 & $3,279,251.93$ & 79.79 \\
\hline Depreciation cost $(\mathrm{R} \$)$ & $794,372.38$ & 20.06 & $830,803.41$ & 20.21 \\
\hline Total cost (TC) (R\$) & $3,977,759.73$ & 100.00 & $4,127,026.11$ & 100.00 \\
\hline Fixed cost (FC) (R\$) & $807,661.36$ & 22.79 & $844,092.40$ & 24.51 \\
\hline Land remuneration $(\mathrm{R} \$)$ & $6,911.52$ & 0.16 & $6,911.52$ & 2.05 \\
\hline Return on capital invested (R\$) & $6,377.47$ & 0.15 & $6,377.47$ & 1.89 \\
\hline Entrepreneur's remuneration ( $\mathrm{R} \$$ ) & 0.00 & 0.00 & 0.00 & 0.00 \\
\hline Taxes considered fixed $(\mathrm{R} \$)$ & 0.00 & 0.00 & 0.00 & 0.00 \\
\hline Depreciation $(\mathrm{R} \$)$ & $794,372.38$ & 19.97 & $830,803.41$ & 20.21 \\
\hline Variable cost (VC) (R\$) & $3,170,098.37$ & 79.70 & $3,282,933.71$ & 79.55 \\
\hline EOC without taxes $(\mathrm{R} \$)$ & $3,166,409.50$ & 79.60 & $3,279,251.93$ & 79.46 \\
\hline Remuneration of working capital (R\$) & $3,688.87$ & 0.09 & $3,681.78$ & 0.09 \\
\hline Gross margin $(\mathrm{R} \$)$ & $3,554,201.60$ & 0.00 & $3,412,138.09$ & 0.00 \\
\hline Gross margin kg milk-1 $(\mathrm{R} \$)$ & 0.87 & - & 0.77 & - \\
\hline Net margin $(\mathrm{R} \$)$ & $2,759,829.22$ & - & $2,581,334.68$ & - \\
\hline Net margin kg milk-1 $(\mathrm{R} \$ / \mathrm{kg})$ & 0.67 & - & 0.58 & - \\
\hline Result (profit or loss) (R\$) & $2,742,851.37$ & - & $2,564,363.91$ & - \\
\hline Result (profit or loss) kg milk (R\$) ${ }^{-1}$ & 0.67 & - & 0.58 & - \\
\hline Profitability $1^{*}(\%)$ & 40.81 & - & 38.32 & - \\
\hline Cost-effectiveness $1^{*}$ (\%) & 16.85 & - & 15.64 & - \\
\hline Profitability 2 (\%) & 41.07 & - & 38.58 & - \\
\hline Cost-effectiveness 2 (\%) & 16.95 & - & 15.75 & - \\
\hline Total amount of milk produced (kg) & $4,102,910.00$ & 100.00 & $4,439,856.00$ & 100.00 \\
\hline Break-even point (kg milk year-1) & $1,008,419.01$ & - & $1,199,658.06$ & - \\
\hline Average milk price $(\mathrm{R} \$)$ & 1.57 & - & 1.44 & - \\
\hline
\end{tabular}

*Indexes calculated using total revenue; Profitability 1: total result/ revenue; Profitability 2: net margin/ total revenue; Cost-effectiveness 1: result/ (EOC + total fixed assets); Cost-effectiveness 2: net margin/ (EOC + total fixed assets) (Lopes et al., 2011a). 
Animal income represented 2.11 and $2.44 \%$ of the total revenue in 2016 and 2017 , respectively. These values are above the $1.84 \%$ observed by Santos and Lopes (2012, 2014), but below the $6.85 \%$ reported by Silva et al. (2019). For Lopes and Santos (2013), the contribution of animal sale to revenue tends to be greater in production systems under the following situations: small farmers whose cows are non-dairy but theoretically dual-purpose; farmers under financial stress at a time of the rise in cattle arroba prices who sell some heads for slaughtering; and in farms where animals are dairy specialized and can also be sold at better prices. Lopes et al. (2011a) found that revenue from animal sales is quite variable and can reach $37.47 \%$. For Lopes and Santos (2013), such variation depends on production system goals and revenue rise needs. By contrast, Demeu et al. (2011) highlighted issues related to herd health aspects.

Revenues were higher than the total operating cost (TOC) of the cost center of milk production studied (Table 2). It shows that all operating expenses can be paid, saving cash for depreciation costs. Silva et al. (2019) also reported revenues higher than TOC. Such findings demonstrate that the cost center of milk production in freestall dairy farms in Brazil can be profitable if managed efficiently.

EOC was $R \$ 3,166,409.50$ and $R \$$ 3,279,251.93 in 2016 and 2017, respectively (Table 2). These represented a money disbursement by the farmer to cover activity costs. The highest value in 2017 was mainly due to a higher number of lactating dairy cows compared to that in 2016. It increases costs with direct disbursements such as animal feed, workforce, electricity, and sanitation. Another factor that may have influenced is the high prices of some inputs. Table 3 displays the monthly detailed expenses composing the EOC. These figures assist technicians and ranchers in planning cash flow since they show in which months the largest (December; $\mathrm{R} \$$ 320,957.96) and lowest (February; R\$ $238,166.53)$ disbursements occur. 


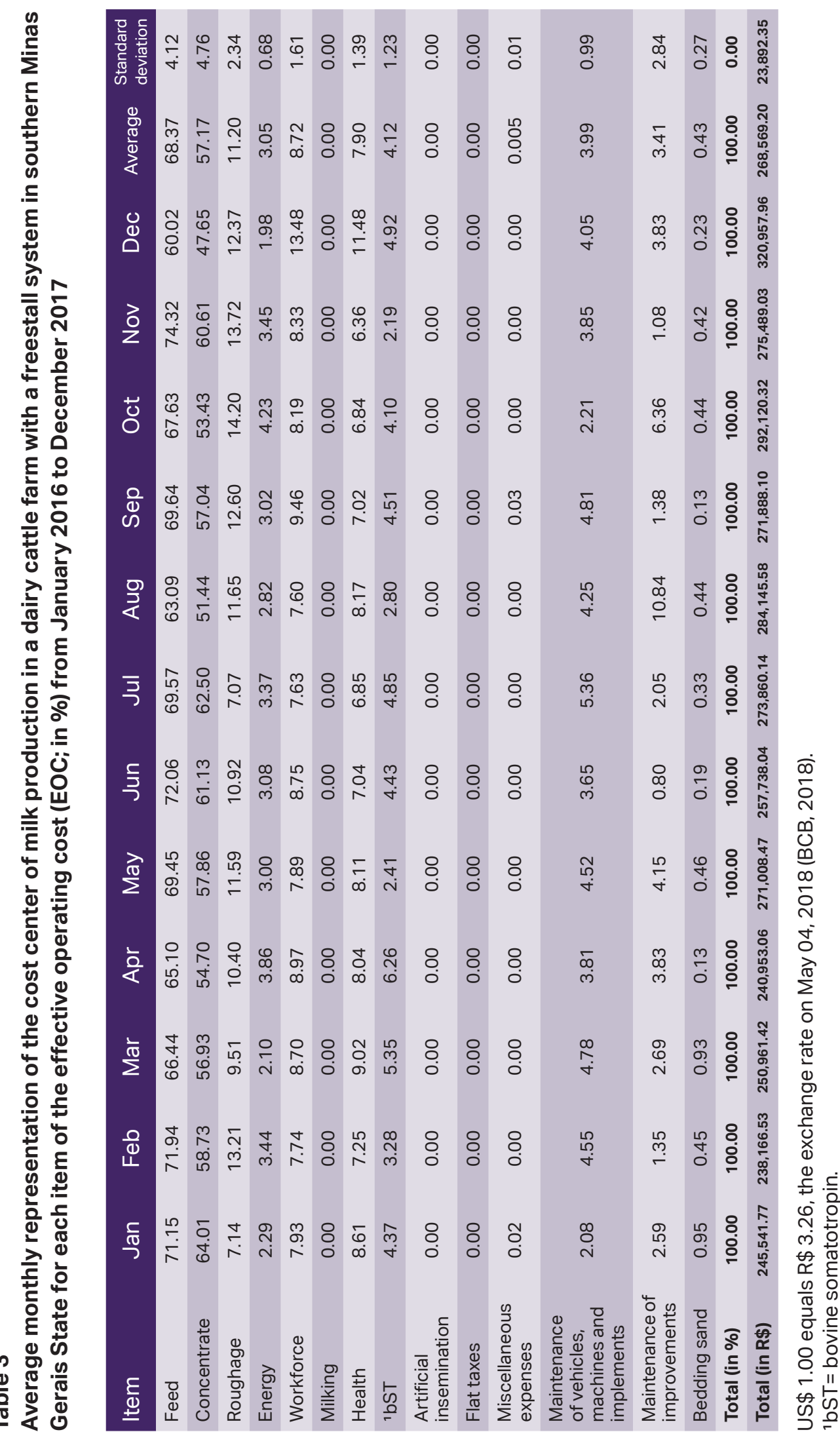


Depreciation represented 20.06 and $20.21 \%$ of the TOC in 2016 and 2017, respectively (Table 2). These are above the $4.97 \%$ and $2.83 \%$ found by Santos and Lopes (2012, 2014), respectively, as well as above the $4.94 \%$ reported by Silva et al. (2019). Such difference may have occurred, at least in part, due to investments in infrastructure, mainly those to minimize environmental impacts. These, in turn, represented, on average, 6.33\% (2016 and 2017) of the total depreciation (Table 1). Another factor that can explain the higher depreciation is the number and quality of animals. This is because cows are purebred by crossing or by origin, so heifers are sold at a higher price ( $\mathrm{R} \$ 8,000.00$ ). Moreover, we considered a $20 \%$ involuntary herd disposal per year and 5-year useful life for depreciation calculation. Therefore, these factors combined increased depreciation. Depreciation of breeding animals alone represented 61.72 and $64.40 \%$ of the total depreciation in 2016 and 2017, respectively. In our study, the number of animals is one of the factors that directly reflected an increase in percentages. This is because the only item that changed depreciation were breeding cows, which increased the TOC by $0.45 \%$. This higher percentage compared to the above-cited studies may be due to the higher number of breeding cows in ours. Noteworthy, in the study of Silva et al. (2019), breeding cow depreciation was disregarded due to its low percentage. If we disregarded it in our study, depreciation would be 8.76 and $8.49 \%$ in 2016 and 2017, respectively. Moreover, if the average depreciation of environmentally friendly technologies (4.88\%) was unconsidered, depreciation would be below that of the aforementioned authors (3.88 and 3.61\%) in 2016 and 2017, respectively. This lower value can be justified by the higher productivity, which "diluted" FC such as depreciation.

$\mathrm{TC}$, which is the sum of fixed and variable costs ( $F C$ and $V C$ ), were $R \$ 3,977,759.73$ and $\mathrm{R} \$ 4,127,026.11$ (Table 2) in 2016 and 2017, respectively. FC was more representative in 2017 (24.51\%) than in 2016 (22.79\%). Lopes, Santos, Resende, Carvalho, and Cardoso (2011a) emphasized that, regardless of the quantity of milk produced, with no acquisition or sale of goods and no increase in taxes considered fixed, they will remain constant. Both production and productivity must be increased to reduce their representativeness in the $\mathrm{TC}$, thus achieving economies of scale. FC can be diluted by increasing production efficiency, producing at scale, and optimizing the use of goods. According to Ferrazza, Lopes, Moraes and Bruhn (2015), these practices can decrease TOC per kg of milk. Yet, VC represented $79.70 \%$ and $79.55 \%$ of the TC in 2016 and 2017, respectively (Table 2).

The cost center of milk production had positive gross and net profit margin results. Therefore, the activity on the farm will be able to survive in the long term if it remains managed in the same way and does not have any unforeseen events.

By analyzing the economic efficiency indicator (gross revenue minus TC), we found positive values for both years analyzed $(R \$$ $2,742,851.37$ and $R \$ 2,564,363.91$ in 2016 and 2017, respectively) (Table 2), thus the activity could remunerate the invested capital.

The indicators profitability 1 and costeffectiveness 1 were higher in 2016 (40.81 and $16.85 \%$, respectively), confirming the good performance of the activity in the cost center of milk production. High indicators like 
that are not so common, which may be due to milk commercialization price ( $R \$ 1.57)$, high daily production $\left(12,163.98 \mathrm{~L} \mathrm{day}^{-1}\right)$, and good milk quality [average somatic cell counts (SCC) below 300,000 cells $\mathrm{mL}^{-1}$ ]. These figures allow ranchers to receive bonuses for milk volume (Demeu, Lopes, Costa, Rocha, \& Santos, 2016; Lopes, Demeu, Costa, Rocha, \& Bruhn, 2017) and quality (Demeu et al., 2015; Lopes et al., 2016). The average prices paid to the studied rancher, according to the CEPEA (Center for Advanced Studies in Applied Economics), were $\mathrm{R} \$ 1.38$ and $\mathrm{R} \$ 1.31$ in 2016 and 2017, respectively. These amounts received were 13.768 and $9.924 \%$ higher than the average prices received by other ranchers in Minas Gerais State. Lopes et al. (2011b) found a decrease in revenue when total somatic cell counts (TSCC) increased.

Profitability 1 was 40.81 and $38.32 \%$ in 2016 and 2017, respectively (total revenue result ${ }^{-1}$ ) (Table 2). This means that for every $R \$$ 100.00 in revenue, there were gains of $R \$ 40.81$ and 38.32 in 2016 and 2017, respectively. By analyzing profitability 2 (net margin total revenue $\left.^{-1}\right)$, the gain was even greater, reaching $\mathrm{R} \$ 41.07$ (Table 2) for each $\mathrm{R} \$ 100.00$ revenue. These values were higher because such indicator disregards remuneration for land, invested capital, entrepreneur pay, and working capital (Lopes et al., 2011a).

The values of cost-effectiveness 1 (result/ [EOC + total fixed assets]) were of 16.85 and $15.64 \%$ (Table 2), while those of costeffectiveness 2 (net margin/ [EOC + total fixed assets]) were of 16.95 and $15.75 \%$ for 2016 and 2017, respectively. An important factor contributing to these high values of profitability and cost-effectiveness was the optimization of the infrastructure of the production system.
Break-even points were 1,008,419.01 and 1,199,658.01 kg year-1 in 2016 and 2017, respectively (Table 2), while total productions were 3,094,490.99 and 3,240,197.94 kg day $^{-1}$ (i.e., well above break-even points). The analyses of economic indicators showed that most, if not all, production resources have been well utilized.

To monitor milk production expenses, the items composing EOC were divided into groups to provide technicians and producers with a more detailed analysis. Animal feed was the item with the highest average representation in both years $(68.37 \% \pm 4.12)$ (Table 3). This is higher than the values found by Silva et al. (2019) (59.37\%), Santos and Lopes (2012) (53.19\%), and Santos and Lopes (2014) (53.17\%). In all months, this item represented the highest percentage of the EOC (Table 3). This, in turn, has a direct effect on the efficiency of purchases, animal productivity, and related input market throughout the year.

Workforce was the second most representative item of the EOC $(8.72 \% \pm$ $1.61 \%$ ) (Table 3 ). This is below the findings of Santos and Lopes (2012) (15.81\%), Silva et al. (2019) (14.10\%), and Santos and Lopes (2014) (15.89\%). The efficiency of this item was most likely due to the use of machines and equipment in several tasks such as spreading of feed and bedding sand, as well as turning of bedding, both in freestalls as in sand recovery areas. The amount of milk produced per worker is also another item to highlight. It averaged 936.74 L in 2016, and 1,013.67 L in 2017, per employee per day. Overall, these values can be considered expressive. Productivity increases contribute to workforce optimization, reducing EOC and hence increasing cost-effectiveness and its representativeness in milk production cost. 
Animal health expenses are related to the use of curative medications (antibiotics, antitoxic, etc.), preventive medications (vaccines, therapeutic antibiotics for dry cows, antiparasitic, etc.), and examinations. The average of such expenses $(7.90 \% \pm 1.39)$ (Table 3 ) was above the $6.08 \%$ found by Silva et al. (2019), 5.22\% by Santos and Lopes (2014), and $5.11 \%$ by Santos and Lopes (2012). Such a high percentage spent on sanitation demands the attention of technicians and ranchers so that herd health problems could be identified and then solved, as quickly as possible, since diseases compromise animal productivity, increase spending on medicines, and may even lead to animal losses.

In terms of energy, average expenditure $(3.05 \% \pm 0.68)$ was below the $4.72 \%$ found by Santos and Lopes (2012) and $4.21 \%$ by Santos and Lopes (2014). The lower percentage found in our study can be justified by electricity generation from biogas, which decreased financial outflow for energy payment.

Miscellaneous expenses represented $0.005 \% \pm 0.1$. It included office supplies, cleaning products, and other items that could not fit into other expense groups. This group had little representativeness because costs with the maintenance of vehicles, machines, and implements, as well as maintenance of improvements, were analyzed separately. Such items have been inserted into the group expenses by other researchers (Yilmaz et al., 2016; Pelegrini et al., 2019; Leite, Lopes, \& Cardoso, 2018). Maintenance of vehicles, machines, and implements was $3.99( \pm 0.99)$ and maintenance of improvements was 3.41 ( \pm 2.84 ), totaling $7.45 \%$, which is close to the $7.59 \%$ found by Santos and Lopes (2014). This small difference can be justified by the conditions of the infrastructures in our study, which were recently implemented and thus have had low maintenance costs.

EOC with freestall bedding sand represented an average of $0.43 \%$ ( \pm 0.27 ) (Table 3 ) and $0.37 \%$ ( \pm 0.025 ) of the TOC. A fact that should be highlighted is that most likely, in our study, the average reclamation of sand from freestall bedding was $96.69 \%$ (estimated percentage considering the difference in the amount of sand acquired before and after implementing the sand reclamation system), which would represent an average of 319.80 $\mathrm{m}^{3}$ year-1; yet acquired sand was on average $484.17 \mathrm{~m}^{3}$ year ${ }^{-1}$. In the study of Silva et al. (2019), the acquisition of sand for freestall bedding represented $0.42 \%$ and $0.40 \%$ of the EOC and TOC, respectively, which is quite close to ours. Freight costs might also have influenced its acquisition value since the farther the farm is from the sand source, the higher the freight cost becomes. In our study, it represented $42.86 \%$ of the total value of sand cubic meter. However, comparisons with other studies could not be made because there is no detail regarding this data.

Records of expenses with the items in the milking group (pre- and post-dipping solutions, acid and alkaline detergents, paper towels, disinfectants and other products used in milking) could not be identified, even though they occurred on the dairy cattle farm studied. Likewise, we could not access the amount disbursed with the item taxes considered fixed, such as ITR and IPVA. Regarding the expenses with breeding (semen, liquid nitrogen, materials for insemination, among others), their percentage was not accounted for in our study because they were considered in the cost center. 
Table 4 shows the costs per liter of milk produced. Emphasis should be given to environmental costs, concerning investments and disbursements related to the implementation of environmentally friendly technologies to minimize the environmental impacts caused by milk production. Total environmental operating cost (TEOC) per $\mathrm{kg}$ milk was $\mathrm{R} \$ 0.0156$ and refers to depreciated amounts ( $R \$ 0.194)$ plus effective environmental operating cost (EEOC), which was $\mathrm{R} \$ 0.0061$ per liter of milk in 2016. EEOC was the sum of the disbursement amounts with the workforce, as well as with maintenance of machines, equipment, and improvements related only to environmentally friendly technologies. It represented only $0.792 \%$ of the EOC in 2016 and $0.765 \%$ in 2017. As for TEOC, it represented 1.615 and $2.036 \%$ of the TOC in 2016 and 2017, respectively. Depreciation of the environmentally friendly technologies represented 1.012 and $0.978 \%$ of the TOC; therefore, it was less representative due to the high benefits provided.

Concerning absolute values in "reais" (Table 4), these few cents invested in environmental preservation seem insignificant, but from a management point of view, they are important and must be accounted for. Thus, in farms with an annual production of 4,439,856 liters, they may add up to $\mathrm{R} \$ 69,261.75$ $(4,439,856 \mathrm{~L} \times \mathrm{R} \$ 0.0156)$ per year. In many cases, it can represent the survival of the activity.

\section{Table 4}

Average unit costs in the cost center of milk production in a dairy cattle farm with a freestall system in southern Minas Gerais State (Brazil) from January 2016 to December 2017, in R\$ and \%

\begin{tabular}{|lcccc|}
\hline \multirow{2}{*}{ Specification } & \multicolumn{3}{c}{ Year: 2016} & \multicolumn{2}{c|}{ Year: 2017} \\
\cline { 2 - 5 } & Total value & $\%$ & Total value & $\%$ \\
\hline Total operating cost (TOC) & 0.965 & 99.573 & 0.926 & 99.589 \\
\hline Effective operating cost of milk & 0.772 & 79.603 & 0.739 & 79.786 \\
\hline Depreciation cost & 0.194 & 20.056 & 0.187 & 20.131 \\
\hline Total cost (TC) & 0.969 & 100.000 & 0.930 & 100.000 \\
\hline Fixed cost (FC) & 0.203 & 20.943 & 0.190 & 20.453 \\
\hline Variable cost (VC) & 0.773 & 79.696 & 0.739 & 79.458 \\
\hline Total environmental operating cost (TEOC) & 0.0156 & 2.020 & 0.0144 & 1.951 \\
\hline Effective environmental operating cost (EEOC) & 0.0061 & 0.792 & 0.0057 & 0.765 \\
\hline Depreciation of environmentally friendly technologies & 0.0095 & 1.228 & 0.0088 & 1.185 \\
\hline Total environmental cost (TEC) & 0.033 & 100.000 & 0.030 & 100.000 \\
\hline Fixed environmental cost (FEC) & 0.019 & 56.490 & 0.017 & 56.490 \\
\hline Variable environmental cost (VEC) & 0.014 & 43.510 & 0.013 & 43.510 \\
\hline Average milk price & 1.57 & - & 1.44 & -
\end{tabular}


Total environmental cost (TEC) per liter of milk was $\mathrm{R} \$ 0.033$ in 2016 and $\mathrm{R} \$$ 0.0030 in 2017 (Table 4) and stood for $3.406 \%$ and $3.225 \%$ of the TC in 2016 and 2017, respectively. It was composed of a sum of fixed environmental costs (FEC) of R 0.019 and $\mathrm{R} \$ 0.017$ in 2016 and 2017, respectively, plus variable environmental costs (VEC) of $R \$$ 0.014 and $\mathrm{R} \$ 0.013$ in 2016 and 2017. FEC ( $R \$ 0.019$ ) consists of remuneration of land and invested capital, as well as depreciation, which represented $1.961 \%$ and 1.828 of the TC in 2016 and 2017, respectively. VEC, in turn, comprised maintenance of infrastructure, machines, and equipment, as well as the remuneration of working capital, and it represented $1.445 \%$ and $1.398 \%$ of the TC in 2016 and 2017, respectively. VEC also represented $1.811 \%$ and $1.759 \%$ of the VC in 2016 and 2017, respectively; while FEC stood for $9.359 \%$ and $8.947 \%$ of the FC in 2016 and 2017, respectively. Such a high percentage of the FC related to environmentally friendly technologies was mainly due to depreciation, which represented 4.03 and $3.86 \%$ of the total depreciation.

Environmentally friendly technologies contributing to cost reduction can be alternatives for sustainability in dairy farming, especially concerning environmental and economic aspects of production systems. In our study, those referring to biodigester, sand reclamation from freestall bedding, and rainwater collection were implemented. However, such investments must not be idle or have no contribution to reductions in production costs.

\section{Conclusions}

Total environmental operating cost, estimated at $\mathrm{R} \$ 0.0156$ and $\mathrm{R} \$ 0.0144$, represented $2.020 \%$ and $1.951 \%$ of the total operating cost in 2016 and 2017, respectively. Effective environmental operating cost was $\mathrm{R} \$ 0.0061$ and $\mathrm{R} \$ 0.0057$ in 2016 and 2017, corresponding to 0.792 and $0.765 \%$ of the total operating cost in 2016 and 2017, respectively. Total environmental cost, estimated at $\mathrm{R} \$$ 0.033 and $\mathrm{R} \$ 0.030$, represented 3.406 and $3.225 \%$ of the total cost in 2016 and 2017, respectively.

The cost center of milk production showed to be economically feasible, with positive gross and net margin results, as well as positive profitability and cost-effectiveness.

The most representative items of the effective operating cost in the cost center of milk production were in decreasing order: animal feed; workforce; animal health; productive hormones (bST); maintenance of vehicles, machines, and implements; maintenance of improvements; energy; and freestall bedding sand.

\section{References}

Assis, L. P., Villela, S. D. J., Lopes, M. A., Santos, R. A. dos, Resende, E. S., Silvestre, L. H. A.,... Martins, P. G. M. de A. (2017). Análise econômica e de custos de produção da atividade leiteira durante 10 anos em uma propriedade do Alto Vale do Jequitinhonha. Custos e @gronegócio On line, 13(2), 176-200.

Banco Central Do Brasil (2018). Dólar americano. Recuperado de http://www4. bcb.gov.br/pec/taxas/port/ptaxnpesq. asp?id=txcotacao 
Bergamaschi, M. A. C. M., Machado, R., \& Barbosa, R. T. (2010). Eficiência reprodutiva das vacas leiteiras. (Comunicado Técnico). São Carlos: EMBRAPA Pecuária Sudeste.

Demeu, F. A., Lopes, M. A., Costa, G. M., Rocha, C. M. B. M. da, \& Santos, G. (2016). Efeito da produtividade diária de leite no impacto econômico da mastite em rebanhos bovinos. Boletim de Indústria Animal, 73(1), 53-61. doi: 10.17523/bia.v73n1p53

Demeu, F. A., Lopes, M. A., Costa, G. M. da, Rocha, C. M. B. M. da, Santos, G. dos, \& Franco, A., Neto. (2011). Influência do descarte involuntário de matrizes no impacto econômico da mastite em rebanhos leiteiros. Ciência e Agrotecnologia, 35(1), 195-202. doi: 10.1590/S1413-70542011 000100025

Demeu, F. A., Lopes, M. A., Rocha, C. M. B. M. da, Costa, G. M. da, Santos, G. dos, \& Franco, A. F. Neto. (2015). Influência da escala de produção no impacto econômico da mastite em rebanhos bovinos leiteiros. Revista Ceres, 62(2), 167-174. doi: 10. 1590/0034-737X201562020006

Ferrazza, R. A., Lopes, M., A., Moraes, F. de, \& Bruhn, F. R. P. (2015). Índices de desempenho zootécnico e econômico de sistemas de produção de leite com diferentes níveis tecnológicos. Semina: Ciências Agrárias, 36(1), 485-496. doi: 10. 5433/1679-0359.2015v36n1p485

Herzog, A., Winckler, C. \& Zollistsch, W. (2018). In pursuit of sustainability in dairy farming: A review of interdependente effects of animal welfare improvement and environmental impact mitigation. (2018). Agriculture, Ecosystems and Environment, 267, 174-187. doi: 10.1016/j. agee.2018.07.029
Instituto Brasileiro de Geografia e Estatística (2018). Indicadores IBGE: sistema nacional de índices de preços ao consumidor. Rio de Janeiro: IBGE. Recuperado de ftp://ftp.ibge. gov.br/Precos_Indices_de_Precos_ao_ Consumidor/IPCA/Fasciculo_Indicadores_ IBGE/ipca-inpc_201807caderno.pdf

Kraemer,M.E.P.(2001). Contabilidadeambiental o passaporte para a competitividade. Revista Catarinense da Ciência Contábil, 1(1), 25-40. doi: 10.16930/2237-7662/ rccc.v1n1p25-40

Leite, I. F., Jr., Lopes, M. A., \& Cardoso, A. A. B. (2018). Rentabilidade e custo da atividade leiteira em Bocaiúva - MG. Nucleus, 15(1), 103-116. doi: 10.3738/1982.2278.2722

Lopes, M. A, Moraes, F. de, Bruhn, F. R. P., Carvalho, F. de M., Lima, A. L. R., Reis, B. E. M., \& Viafara, J. A. S. (2019). Análisis de larentabilidad de laactividadlechera de propriedades participantes del programa "Balde Cheio". Revista de Medicina Veterinária, 38(1), 15-27. doi: 10.19052/ mv.vol1.iss38.2

Lopes, M. A., \& Santos, G. dos. (2013). Análise de rentabilidade de fazendas leiteiras em regime de semiconfinamento com alta produção diária. Informações Econômicas, 43(3), 65-74.

Lopes, M. A., Demeu, F. A., Costa, G. M. da, Rocha, C. M. B. M. da, \& Bruhn, F. R. P. (2017). Representatividade de diferentes fatores no impacto econômico da mastite em rebanhos leiteiros. Boletim de Indústria Animal, 74(2), 135-147.

Lopes, M. A., Demeu, F. A., Costa, G. M. da, Rocha, C. M. B. M. da, Abreu, L. R. de, Santos, G. dos, \& Franco, A., Neto. (2011b). Influência da contagem de células somáticas sobre 
o impacto econômico da mastite em rebanhos bovinos leiteiros. Arquivos do Instituto Biológico, 78(4), 493-499. doi: 10.1590/18 880-1657v78p4932011

Lopes, M. A., Franco, A., Neto, Santos, G. dos, Demeu, F. A., Lopes, L. M. F., \& Moreira, S. R. (2010). Custos de produção de fêmeas bovinas da raça holandesa nas fases de cria e recria em um sistema de produção de leite no sul de Minas Gerais. Boletim De Indústria Animal, 67(1), 9-15. Recuperado de http://www.iz.sp.gov.br/bia/index.php/ bia/article/view/1086

Lopes, M. A., Moraes, F., Carvalho, F., Peres, A., Bruhn, F., \& Reis, E. (2015). The effect of technological levels on profits of milk production systems participating in the "full bucket" program: a multicase study. Semina: Ciências Agrárias, 36(4), 29092922. doi: 10.5433/1679-0359.2015v36n 4p2909

Lopes, M. A., Reis, E. M. B., Demeu, F. A., Mesquita, A. A., Rocha, A. G. F., Pelegrini, D. F.,... Teixeira Junior, F. E. P. (2016). Uso de ferramentas de gestão na atividade leiteira: um estudo de caso no sul de Minas Gerais. Revista Científica de Produção Animal, 18(1), 26-44. doi: 10.25066/ agrotec.v39i1.34302

Lopes, M. A., Santos, G. dos, \& Carvalho, F. de M. (2011d). Indicadores econômicos da atividade leiteira em regime de semiconfinamento com alta produção diária. Boletim de Indústria Animal, 68(2), 113-123.

Lopes, M. A., Santos, G. dos, Franco, A., Neto, Lopes, L. M., Demeu, F., \& Resende, B. (2012). Resultados econômicos de um sistema de produção de leite no município de Itutinga - MG. Boletim de Indústria Animal, 69(1), 23-31. Recuperado de http://www.iz.sp.gov.br/bia/index.php/bia/ article/view/1043

Lopes, M. A., Santos, G. dos, Resende, M. C. Carvalho, F. de M., \& Cardoso, M. G. (2011a). Estudo da rentabilidade de sistemas de produção de leite no município de Nazareno, MG. Ciência Animal Brasileira, 12(1), 58-69.

Moraes, F., Lopes, M. A., Carvalho, F. M., Peres, A. A. C., Bruhn, F. R. P., Lima, A. L. R., \& Cardoso, M. G. (2018). Effect of the scale of production on the cost-effectiveness of milk production systems belonging to the "BaldeCheio" program. Semina: Ciências Agrárias, 39(3), 1211-1224. doi: 10.5433/ 1679-0359.2018v39n3p1211

Moura, J. F. P. de, Pimenta, E. C., Fo., Gonzaga, S., Neto, Leite, S. V. F., Guilhermino, M. M., \& Menezes, M. P. C. (2010). Análise econômica da exploração de leite no Cariri Paraibano. Acta Scientiarum. Animal Sciences, 32(2), 225-231. doi: 10.4025/ actascianimsci.v32i2.7115

Pelegrini, D. P., Lopes, M. A., Demeu, F. A., Rocha, A. G. F., Bruhn, F. R. P., \& Casas, O. S. (2019). Effect of socioeconomic factors on the yields of family-operated milk production systems. Semina: Ciências Agrárias, 40(3), 1199-1214. doi: 10.5433/1679-0359.2019v40n3p1199

Reddy, P. R. K., Kumar, D. S., Rao, E. R., Seshiah, C. V., Sateesh, K., Rao, K. A.,... Hyder, I. (2019). Environmental sustainability assessment of tropical dairy buffalo farming vis-a-vis sustainable feed replacement strategy. Scientific Reports, 9, 1-16. doi: 10.1038/ s41598-019-53378-w 
Reis, E. M. B., Lopes, M. A., Santos, G., \& Guimarães, A. M. (2018). Custo de produção de fêmeas bovinas leiteiras durante a fase de cria e recria: um estudo de caso. Medicina Veterinária (UFRPE), 12(1), 37-40. doi: 10.26605/medvet-v12 $\mathrm{n} 1-2157$

Santos, I. A. dos. (2012b). Emissões de Gases de Efeito Estufa (GEE) associadas à bovinocultura: o valor fertilizante do esterco e o impacto da biodigestão anaeróbia. Dissertação de mestrado, Universidade Federal de Itajubá, Itajubá, MG, Brasil. Recuperado de https://repositorio.unifei.edu.br/xmlui/ bitstream/handle/123456789/1204/ dissertacao_santos 1_2012. pdf?sequence=3\&isAllowed=y

Santos, G. dos, \& Lopes, M. A. (2012). Indicadores de rentabilidade do centro de custo produção de leite em sistemas intensivos de produção. Boletim de Indústria Animal, 69(1), 1-11. Recuperado de http://www.iz.sp.gov.br/bia/index.php/ bia/article/view/1042

Santos, G. dos., \& Lopes, M. A. (2014). Indicadores econômicos de sistemas de produção de leite em confinamento total com alto volume de produção diária. Ciência Animal Brasileira, 15(3), 239-248. doi: 10.1590/1809-6891v15i314045
Silva, G. R. de O., Lopes, M. A., Lima, A. L. R., Costa, G. M. da, Damasceno, F. A., Barros, V. P., \& Barbari, M. (2019). Profitability analysis of compost barn and free stall milk-production systems: a comparison. Semina: Ciências Agrárias, 40(3), 11651184. doi: 10.5433/1679-0359.2019v40n 3p1165

United Nations General Assembly (1992). Conferência das Nações Unidas sobre meio ambiente e desenvolvimento. Recuperado de https:// sustainabledevelopment.un.org/content/ documents/Agenda21. pdf

United Nations General Assembly (2015). Agenda 2030 para o desenvolvimento sustentável. Recuperado de https:// www.un.org/ga/search/view_doc. asp?symbol=A/RES/70/1\&Lang=E

Yilmaz, H., Gül, M. E., Akkoyun, S., Parlakay, O., Bilgili, M. E., Vurarak, Y.,... Kilicalp, N. (2016). Econmic analysis of dairy cattle farms in east Mediterranean region of Turkey. Revista Brasileira de Zootecnia, 45(7), 409-416. doi: 10.1590/S1806-9290 2016000700008 